\title{
EU COMPETITIVENESS \& ECONOMIC SHOCKS: COMPOSITE WEIGHTED INDEX OF REGIONAL RESILIENCE
}

\author{
Michaela Staníčková \\ Lukáš Melecký
}

VŠB-Technical University of Ostrava, Faculty of Economics, Czech Republic

Since 2008, the world has faced the economic crisis that has had devastating effects on many regions to various degrees. How regions respond to economic shock depends on regional economic structure and performance, administrative capacity, resources, human capital, social capital, and other factors, were perceived as resilience. Resilience has recently risen to prominence in several disciplines, has also entered policy discourse, and is one of the future strategic goals for the European Union. The aim of the paper is to introduce a methodology for assessing the resilience of EU28 NUTS 2 regions based on a construction of composite weighted index derived from EU Regional Competitiveness Index database of indicators using Factor analysis and their classification by Cluster analysis. Construction of composite indicators includes several steps that have to be made and corresponding methods have to be chosen to handle different aspects of economic issues including features of EU resilience.

Keywords: cluster analysis, crisis, economic shock, entropy method, European Union, factor analysis, indicators, nuts 2 region, weighting scheme

\section{Introduction}

It is generally accepted that the level of economic development is not uniform across territories. On the contrary, it substantially differs. This plays an important role in many

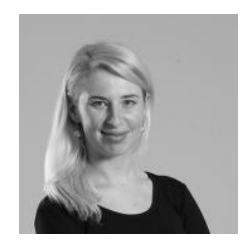

Michaela Staníčková

is an Assistant Professor of economic science (since 2014) at the VŠB-Technical University of Ostrava, Faculty of Economics, and Department of European Integration in the Czech Republic. Her scientific interests are the EU competitiveness (in line with efficiency and effectiveness of public spending and the EU resilience to economic shocks), and implementation of the EU structural aid through projects co-financed by the EU funds. She is (or was) member of several international or national research projects. Since 2010, she published seven papers in scientific books, 18 articles in professional journals, many papers in conference proceedings, of which 26 records registered in the Thomson Reuters database and 10 records in Scopus database.

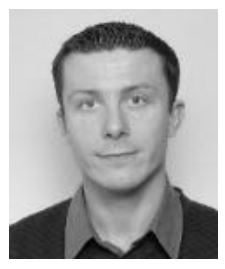

Lukáš Melecký

is an Assistant Professor of economic science (since 2004) at the VŠB-Technical University of Ostrava, Faculty of Economics, and Department of European Integration in the Czech Republic; and head of Department of European Integration (since 2016). His scientific interests are aspects of regional disparities, cohesion and competitiveness of EU Member States and regions, implementation of the EU Cohesion policy and programming of EU structural aid in the regional development of the Czech Republic through preparation of projects proposals co-financed by the European funds. He is (or was) member of several international or national research, pedagogical and development projects. He is co-author of one monograph, he published seven papers in scientific books, 21 articles in professional journals, many papers in conference proceedings, of which 24 records registered in the Thomson Reuters database and 4 records in Scopus database. 
research studies that made to assign an appropriate evaluation of economic and social development in European area (Balcerowicz et al., 2013, Easterly \& Levine, 2012, Watt \& Botsch, 2010, Ghosh et al., 2009). As human activities are related to economic development and affected by territorial development, the way of measurement of the conditions of national development is really essential and important in the determination of a country's socio-economic policies (Halkos \& Tzeremes, 2005). The issue of socio-economic advancement but also disparities of territories closely link to the setting and evaluation of competitiveness (Gardiner, Martin \& Tyler, 2004, Ocubo, 2012). The dynamics of economic, social, political and cultural change in the contemporary world increasingly shape by the pursuit and promotion of competitiveness. The economy may be competitive but if the society and the environment suffer too much the country will face major difficulties, e.g. in the form of economic crisis, and its competitive and comparative advantages and disadvantages are subject to evolution and adaptation with respect to these processes (Fojtíková, 2016).

Starting in 2008, an economic crisis with no comparable precedent after WWII has affected most of the World, and Europe in particular. Yet, despite the pervasiveness of the crisis, it has affected differently different European Union (EU) countries, with some countries losing a very large number of jobs, and others being able to maintain employment. At the same time, for some countries, the burden on public finances due to increasing interest rates has become un-tractable, while others have been able to maintain public finances under control, also thanks to a lower starting debt. Global economic changes have caused problems for both individuals and businesses, affecting entire economic sectors, regions, and their socioeconomic structures. Therefore, also EU is facing one of the most difficult periods since its establishment, with multiple challenges for the policy-makers mainly at the regional level. Recent years have seen a myriad of economic and social difficulties, i.e. stagnating economic growth, rising unemployment leading to social tensions, continuing financial troubles and sovereign debt crises in several European countries, exacerbated by the fact that the outlook remains uncertain. There is widespread agreement that the root causes of this prolonged crisis lie in the lack of competitiveness of many countries. The EU faces increased competition from other continents, their nations, regions and cities. Territorial potentials of European regions and their diversity are thus becoming increasingly important for the resilience and flexibility of the European economy, especially now in times of globalisation processes in the world economy. The EU, its regions and larger territories are increasingly affected by developments at the global level. New emerging challenges influence the territorial development and require policy responses. Territorial imbalances on the other hand challenge economic, social and territorial resilience in the EU (Staníčková, 2016).

Resilience measurement and evaluation at any level of territorial development is frequently associated with the lack of integrated approaches and methodologies. Within this paper, the application of integrated approach by using the construction of five composite non-weighted indices and one composite weighted index of regional resilience are introduced in the frame of Regional Competitiveness Index (RCI) approach in 273 EU28 NUTS 2 regions. Resilience in the frame of regional competitiveness is a major obstacle to the balanced and harmonious development of the regions, but also of the whole territory. Analysis of resilience may bring the important information about the key problematic issues in the region (and thus in the country) on the one side and its development potential on the 


\section{EU COMPETITIVENESS \& ECONOMIC SHOCKS:}

other side. The main goal of the paper is to introduce the construction of specific composite weighted index and verify this approach through brief empirical analysis and evaluation of selected economic, social and territorial indicators that reflect the level of regional resilience in EU28 NUTS 2 regions using most recent data from RCI approach. For this purpose, the paper determinates and computes five factors of regional resilience and proposes a construction of Composite Weighted Index of Regional Resilience (CWIRR) for EU28 NUTS 2 regions. The paper hypothesis is based on the general concept of regional competitiveness presented e.g. by Gardiner, Martin \& Tyler (2004) or Bristow (2005). Regions with the lower level of productivity and ability to create and maintain an environment that sustains more value creation for its enterprises and more prosperity for its people' prosperity, achieve the lower level of resilience in the territory that provides worse conditions and assumptions for regional development potential, and vice versa. The paper, in the content of the previous hypothesis, intends to establish the general presumption that in NUTS 2 regions of (more) developed EU28 Member States is a higher level of regional resilience in comparison with the level of regional resilience in NUTS 2 regions of less developed EU28 Member States.

\section{Resilience and Crisis}

Macroeconomic country-level effects are very important, but and also within countries the impact on the various regions has been far from uniform, with some regions, often the urbanist, able to resist the crisis better than others. Economic crisis has presented many challenges to policy planners, who are trying to protect countries from negative effects and are seeking solutions for more resilient development in the future. The structure of countries is hence an important determinant of how they can afford periods of distress and contemporary regional development issue is enriched with the concept of regional resilience.

\section{Resilience: Concept and Literature Review}

Economic shocks occur periodically to economies, though the effect that these shocks have varies from region to region as does the region's adjustment and recovery to them. Authors are particularly concerned with regional economic resilience: why are some regional economies that are adversely affected by shocks able to recover in a relatively short period while others are not? Economic resilience is a concept frequently used, but rarely well defined. The concept of resilience is routinely used in research in disciplines ranging from environmental research to materials science and engineering, psychology, sociology, and economics. The notion of resilience is commonly used to denote both strength and flexibility. Conceptually, there are two separate but not necessarily unrelated, concepts. The first bases on 'equilibrium analysis' in which resilience is the ability to return to a preexisting state in a single equilibrium system. The second defines resilience in terms of 'complex adaptive systems' and relates to the ability of a system to adapt and change in response to stresses and strains (Pindus et al., 2012). The term implies both the ability to adjust to 'normal' or anticipated levels of stress and to adapt to sudden shocks and extraordinary demands. In the context of hazards, the concept thought of as spanning both 
prevent measures that seek to prevent hazard-related damage and losses and post-event strategies designed to cope with and minimise disaster impacts.

For regional economic analysis, perhaps the most natural conceptual meaning of economic resilience is the ability of a regional economy to maintain or return to a preexisting state (typically assumed an equilibrium state) in the presence of some type of exogenous shock. Although only a few studies use the term 'resilience' explicitly. The economic literature dealing with the idea of resilience typically concerns with the extent to which a regional or national economy is able to return to its previous level and/or growth rate of output, employment, or population after experiencing an external shock, see e.g. Blanchard \& Katz (1992), Rose \& Liao (2005), Briguglio et al. (2006) or Feyrer, Sacerdote $\&$ Stern (2007). Competitiveness expects to contribute to the economic performance and welfare of cities, firstly by enhancing attractivity for international capital; secondly, to enable local agents to export their products and services all over the world and join global value chains. Thirdly, to acquire global functions that will allow them to benefit from the spill over effects of the global circulation of knowledge, information and technology. Competitiveness can be attained with different assets that define to what extent a particular region is able to integrate into the global economy. However, the existing assets of competitiveness can be quickly eroded, since their effects may differ from place to place. More importantly, the reliance on global conditions and the dominance of deregulatory measures make regions vulnerable in economic terms. The financial crisis of the recent past has led to deep economic problems in many countries, which is just one example of how problems in local economies can easily disseminate within the global economy and can cause complications even in countries with relatively stable economies. The dependence on global markets and the conditions imposed by global capital has also very important implications on performance and resilience (Eraydin, 2013, pp. 20-21).

Opinions vary to the definition of resilience, and there is no mainstream approach for measurement and expression of resilience and therefore no uniform strategies for strengthening the resilience of economies. Quantifying systems and regional resilience is a complex process, and scales for measuring resilience, at any level, do not currently exist. What are the main characteristics of regional resilience? The first group of factors suggests Martin (2012) and among the key factors of regional resilience ranks: dynamic growth of the region, the structure of the economy, export orientation and specialisation of the region, human capital, innovation rate, business and corporate culture, localisation of region, and institutional arrangement in the region. The second group of factors defines Foster (2006) and among the key factors of regional resilience suggests regional economic capacity, the socio-demographic capacity of the region and regional community capacity. In the Czech Republic, Koutský et al. (2012) engage issues of regional resilience determinants and define following factors: the main macroeconomic indicators, labour market indicators and additional ones. Based on these three sets of factors of regional resilience, the authors can define (with a certain degree of generalization proceed) a set of indicators of regional resilience which are also important in terms of competitiveness (based on common relation), see (Melecký, Staníčková, 2015 a, b) and this approach will be used for purposes of this paper. In the paper, the authors link the concepts of resilience with competitiveness. It is very important to understand the extent to which areas (territories/localities or regions) compete with each other, where this competition comes from, and what factors determine a territorial economic attractiveness. Taking the competitiveness concept a step further, 


\section{EU COMPETITIVENESS \& ECONOMIC SHOCKS:}

understanding territorial resilience challenges allows not only thinking about wealth generation of our territories, but also ensuring the wellbeing of all citizens, enabling sustainable economic development, and how to manage economic shocks and decline into our territorial strategies (Tamásy \& Diez, 2013). The authors point out that regional resilience has certainly influenced by the nature state economic policy, export-orientation of regions, business and corporate culture, institutional arrangement of regions and other factors. However, the above indicators are considered as the basic initial research in this area.

\section{Crisis and Territorial Consequences}

Despite the growing importance of socioeconomic resilience during the current period of economic crisis, this concept has not been carefully defined or satisfactory measured within the more general issue of socioeconomic resilience. This concept has received increasing interest in Europe, particularly in the time of several times mentioned the issue, i.e. economic crisis and external shocks. In this meaning, a long-term, holistic perspective, in contrast, would emphasise the structure of relationships among macroeconomic variables that persists over a long period and the economic, political and social institutions that condition this structure (Reich, 1997). As an example, a social structure is not static; although it persists for a long time, it evolves in ways that ultimately threaten firms' profitability and long-term macroeconomic growth. Economic systems that experience negative shocks may exhibit three different kinds of responses. Some of these may have returned to or exceeded their previous growth within a relatively short period; these regions might be called economically resilient. Some may not has been thrown off their growth path at all; these regions might be called shock-resistant. Finally, some regions may have been unable to rebound and return to or exceed their previous path; these can be called nonresilient (Mancini et al., 2012). To implement a socioeconomic resilience measure is necessary to address a series of measurement issues (as will be discussed below), and especially consequences of economic shocks.

Economic shocks occur periodically to economies, though the effect that these shocks have varies from region to region as does the region's adjustment and recovery to them. The paper is particularly concerned with economic resilience: why are some economies that are adversely affected by shocks able to recover in a relatively short time-period while others are not? There is widespread agreement that effective and efficient way to respond the economic shocks is to improve the economic resilience of the territories, also in the case of economic policies as the reaction on economic crisis starting in 2008 (Staníčková, 2016). A number of scholars agree in considering the recent financial crisis one of the most severe economic crises in post-war economic history (Arestis, Sobreira \& Oreiro, 2011). The 2008 global economic crisis has been the most severe economic recession since the Great Depression. Far from being limited to the instabilities of some of the world's largest private financial institutions, as it appeared to be at the early stages, the financial crisis gradually turned into a global economic crisis, resp. economic recession based on the theory of economic cycle and its phases. The pervasiveness and geographical heterogeneity of its impacts have attracted increasing interest in understanding how and why territories, local and regional economies react to economic shocks. 
In the EU, the crisis interrupted constant average GDP growth and employment growth, opening the doors of several countries to the economic recession. The recession technically started in the first quarter of 2008 and lasted until the last quarter of 2009. Between the second half of 2010 and 2011, the EU recorded a second wave of negative economic growth. Whereas the recession has influenced the majority of European countries, its depth has been highly unequal across the Continent and its long-term impacts are likely to be similarly uneven (Crescenzi, Luca \& Milio, 2016). As argued by earlier policy reports and academic papers, the proper understanding of the recession impacts upon which to modulate future regional policies calls for a perspective able to take into account the different geographies and intensities of the social, economic and territorial dynamics triggered by the downturn. The recession is, in most EU Member States, a private debt crisis that turned into a sovereign debt crisis (Milio et al., 2014). These two different, yet intertwined, phases of the crisis have followed successive paths, with the outbreak of the private debt crisis in 2008 and the subsequent uprising of the sovereign debt crisis in 2010. The Economic recession in a severe downturn, leading to a slump in demand, a fall in economic output and increasing unemployment. Europe was no longer clearly moving towards economic and social cohesion (Melecký, 2015). The territorial impacts are asymmetrical. The impacts of the recession vary greatly throughout Europe and not all countries and regions experienced economic decline. The important point is the fact that crisis developed at different times and 'Resilience' has become an increasingly significant concept in European policymaking.

\section{Conclusion}

Bringing together different development factors, which illustrate single aspects of competitiveness, gives a first impression of the overall competitiveness of EU Member States and shows the diversity that exists within the EU territory. Among the important driving forces influencing future territorial development are demographic development (including migration), economic integration, transport, energy, agriculture and rural development, climate change, further EU enlargements and territorial governance. Very important role-play exogenous factors having the impact on regional competitiveness. Current theories of regional competitiveness emphasise the significance of soft factors such as human, cultural (knowledge and creativity) and socio-institutional capital, environmental quality, etc. A wide range of soft location factors is thus of increasing importance. Soft factors like governance, culture and natural environment are part of territorial potentials and offer synergies for the jobs and growth agenda. The potentials for these soft factors differ widely between areas. Quality living environments and access to environmental and cultural amenities are among factors that attract investment and people to a location what is very important for competitiveness for each country and its competitive advantage and factor endowment. Currently, hazards (also in the form of economic crisis) do not undermine the competitiveness of a region. Only a few places have very low exposure to the main natural and technological hazards in Europe, and climate change is expected to increase the risk of hazards in the future. To gaze into the future it is necessary to understand the driving forces that shape territorial development and various possible future developments and interrelations with the territory each driving force might bring. Bringing them together into 


\section{EU COMPETITIVENESS \& ECONOMIC SHOCKS:}

integrated prospective scenarios is then the final challenge, which should help to be resistant to crisis.

This paper presented a framework for defining regional resilience and specifying quantitative measures of resilience that can serve as foci for comprehensive characterization of the socio-economic problem to establish needs and priorities. Regional resilience is a much broader concept beyond the economic dimension. It is also reasonable to assume that application of similar indices at the lower territorial level will require adaptation to national conditions and specifics.

The framework integrates measures into five dimension of regional resilience: Community links (CL), Human capital and Socio-demographic structure (HC-SDS), Labour market (LM), Economic performance (EP) and Innovation, science and research (ISR), all of which can be used to quantify measures of resilience for various types of regional systems what could serve for establishing the tasks required to achieve required objectives. Regional resilience is a much broader concept beyond the economic dimension. This framework makes it possible to assess and evaluate the contribution to the resilience of various activities implemented in regions, whether focusing on components, systems, or organisations, with applications ranging from lifelines and building systems to the organisations that provide critical services. Well-defined and consistently applied quantifiable measures of resilience make it possible to carry out various kinds of comparative studies (e.g., to assess the effectiveness of various loss-reduction measures, such as structural problems), to determine why some regions are more resilient than others are, and to assess changes in regions resilience over time.

The ultimate objective is to propose the concept of regional resilience index, which is presented in the paper. Because it takes a long time to change the regional characteristics that affect resilience-related outcomes, policies and strategies that are put in place after a region has experienced an economic shock are challenging activities, what is our future research orientation. In the framework of preliminary results, while a planning process that follows communicative rationality is to be used in shaping the planning process, the methods defined within the context of decision-making can be used to define background or remove red tape to achieve no-regret conditions in the long term. With respect to the results, some countries and their regions are more resilient when confronted with economic shocks than others are. These regions are either less affected by such shocks on impact and/or they recover more quickly. Consequently, countries and regions cannot be understood as the only decisive factors in providing resilience because they strongly depend on the macroeconomic framework conditions of the entire country. Therefore, the first step towards more resilient economies should be made at the national level, providing attractive socioeconomic conditions such as an innovation-friendly tax system, openness to foreign investment, a competitive business environment, a flexible employment system, and, above all, a trustworthy and stable political system that plays an important role in confidence building while interacting at international level.

\section{Acknowledgement}

The paper is supported by the SGS project (SP2017/111) of Faculty of Economics, VŠB-TUO, Czech Science Agency junior project (17-23411Y) and the Operational Programme Education for Competitiveness - Project No. CZ.1.07/2.3.00/20.0296. 


\section{References:}

Arestis, P., Sobreira, R. \& Oreiro, J. L. (2011). The financial crisis origins and implications. London, UK: Palgrave Macmillan.

Balcerowicz, L. et al. (2013). Economic Growth in the European Union. Brussel, BE: Lisbon Council.

Blanchard, O. \& Katz, L. F. (1992). Regional Evolutions. Brookings Papers on Economic Activity, 1, $1-75$.

Briguglio, L. et al. (2006). Conceptualizing and Measuring Economic Resilience. Building the Economic Resilience of Small States, 2(3), 265-287.

Bristow, G. (2005). Everyone's a 'winner: problematizing the discourse of regional competitiveness. Journal of Economic Geography, 5(3), 285-304.

Crescenzi, R., Luca, D. \& Milio, S. (2016). The geography of the economic crisis in Europe: national macroeconomic conditions, regional structural factors and short-term economic performance. Cambridge Journal of Regions, Economy and Society, 9(1), 13-32.

Eraydin, A. (2013). Resilience Thinking for Planning, in Resilience Thinking in Urban Planning. Springer Science+Business Media Dordrecht, pp. 17-37.

Easterly, W. \& Levine, R. (2012). The European origins of economic development. NBER Working Paper Series 18162. Retrieved January 17, 2017, from http://www.nber.org/papers/w18162

Feyrer, J., Sacerdote, B. \& Stern, A. D. (2007). Did the Rust Belt Become Shiny? A Study of Cities and Counties That Lost Steel and Auto Jobs in the 1980s. Brookings-Wharton Papers on Urban Affairs, 41-102. doi 10.1353/urb.2007.0005

Fojtíková, L. (2016). Trends in the revealed comparative advantages of the EU member states. ECONOMIC ANNALS-XXI, 161(9-10), 7-11.

Foster, K.A. (2006). A Case Study Approach to Understanding Regional Resilience. Working paper 2007-08. Berkeley: Institute of Urban and Regional Development, pp. 1-45.

Gardiner, B., Martin, R. \& Tyler, P. (2004). Competitiveness, Productivity and Economic Growth across the European Regions. Regional Studies, 38(1), 1045-1067.

Ghosh, J. et al. (2009). Models of BRICs' Economic Development and Challenges for EU Competitiveness. Vienna, AT: The Vienna Institute for International Economics Studies.

Halkos, G. \& Tzeremes, N. (2005). A DEA approach to regional development. Munich, DE: University Library of Munich.

Koutský, J. et al. (2012). Profilace měkkých faktorů regionálního rozvoje jako nástroj posilování regionální odolnosti a adaptability. Certifikovaná metodika Ministerstva pro místní rozvoj. Prague, CZ: MMR.

Mancini et al. (2012). Conceptualizing and Measuring the Economic issues in the Evaluation of Socio-ecological Resilience: A Commentary. International Journal of Latest Trends in Finance and Economic Sciences, 3(2), 190-196.

Martin, R. (2012). Regional Economic Resilience, Hysteresis and Recessionary Shocks. Journal of Economic Geography, 12(1), 1-32.

Melecký, L. (2015). Assessment of Socioeconomic Development of Visegrad Four NUTS 2 regions Using Composite Indices. In Proceedings of $12^{\text {th }}$ International Conference Economic Policy in the European Union Member Countries (pp. 561-571). Karviná, CZ: Silesian University.

Melecký, L. \& Staníčková, M. (2015a). Assessment of EU Regional Resilience Using Composite Index. In Proceedings of the 13th International Conference Economic Policy in the European Union Member States Countries (pp. 382-395). Ostrava, CZ: Vysoká škola báňská - Technická univerzita Ostrava.

Melecký, L. \& Staníčková, M. (2015b). Weighting Scheme for Measuring the Composite Index of EU Regional Resilience. In Proceedings of the 33rd international conference Mathematical Methods in Economics, (pp. 525-530). Plzeň, CZ: University of West Bohemia.

Milio, S. et al. (2014). Impact of the Economic Crisis on the Economic, Social and Territorial Cohesion of the European Union. Brussel, BE: European Parliament. 


\section{EU COMPETITIVENESS \& ECONOMIC SHOCKS:}

Ocubo, T. (2012). Antiagglomeration subsidies with heterogeneous firms. Journal of regional science, 52(2), 285-287.

Pindus, N., Weir, M., Wial, H. \& Wolman, H. (2012). Building Resilient Regions: Urban and Regional Policy and Its Effects. Washington, USA: Brookings Institution Press.

Reich, M. (1997). Social Structure of Accumulation Theory: Retrospect and Prospect. Review of Radical Political Economics, 29(1): 1-10.

Rose, A. \& S. Liao. (2005). Modeling Regional Economic Resilience to Disasters: A Computable General Equilibrium Analysis of Water Service Disruptions. Journal of Regional Science, 45(1), 75-112.

Staníčková, M. (2016). EU Resilience to Economic Crisis: Is the Applicability of Resilience Concept Realistic? In Proceedings of the 14th International Scientific Conference Economic Policy in the European Union Member Countries (pp. 638-648). Opava, CZ: Silesian University in Opava, School of Business Administration in Karvina.

Tamásy, Ch. \& Diez, J.R. (2013). Regional Resilience, Economy and Society. Farnham, UK: Ashgate.

Watt, A. \& Botsch, A. (2010). After the crisis: towards a sustainable growth model. Brussel, BE: European Trade Union Institute.

Paper submitted

Paper accepted for publishing

Paper pubslihed on-line
17 August 2017

11 October 2017

01 February 2018 